\title{
Efikasi Ekstrak Daun Kemangi (Ocimum basilicum) Terhadap Penyakit Bercak Daun (Cercospora arachidicola) Pada Kacang Tanah
}

\author{
Author(s): Rosita Meliyana*(1); Rudi Wardana(1); Mochamad Syarief ${ }^{(1)}$ \\ (1) Jurusan Produksi Pertanian, Politeknik Negeri Jember \\ * Corresponding author: rositameliyana.tpp@gmail.com
}

\begin{abstract}
ABSTRAK
Cercospora arachidicola merupakan patogen yang menyebabkan penyakit bercak daun pada tanaman kacang tanah. Serangan penyakit bercak daun pada tanaman kacang tanah dapat menurunkan hasil akibat patogen yang menyerang pada saat pengisian polong. Penggunaan pestisida sintetik dalam pengendalian penyakit tanaman dapat menimbulkan efek residu yang membahayakan lingkungan. Untuk mengurangi dampak negatif tersebut diperlukan upaya perlindungan tanaman dengan penggunaan pestisida nabati. Penelitian ini bertujuan untuk mengetahui efikasi ekstrak daun kemangi terhadap penyakit bercak daun (Cercospora arachidicola) pada tanaman kacang tanah. Penelitian ini dilaksanakan pada November 2017 sampai Februari 2018 di lahan percobaan Desa Baratan, Kecamatan Patrang, Kabupaten Jember dan laboratorium perlindungan tanaman Politeknik Negeri Jember. Penelitian mengunakan rancangan acak kelompok (RAK) non faktorial 5 perlakuan dengan (P0) fungisida sintetik $1 \mathrm{ml} /$ liter, ekstrak daun kemangi 25 $\%(\mathrm{P} 1)$, ekstrak daun kemangi 50\% (P2), ekstrak daun kemangi $75 \%$ (P3), dan ekstrak daun kemangi $100 \%(\mathrm{P} 4)$. Hasil uji anova pada penelitian menunjukkan bahwa efikasi ekstrak daun kemangi (Ocimum basilicum) terhadap penyakit bercak daun (Cercospora arachidicola) pada tanaman kacang tanah tidak berbeda nyata pada parameter intensitas serangan, jumlah polong, berat basah polong, dan berat kering polong kacang tanah. Peningkatan serangan Cercospora arachidicola berdampak dalam pengurangan hasil panen kacang tanah pada uji korelasi.
\end{abstract}

Kata Kunci:

Ekstrak daun kemangi;

Cercospora arachidicola;

Kacang tanah;

Penyakit bercak daun;

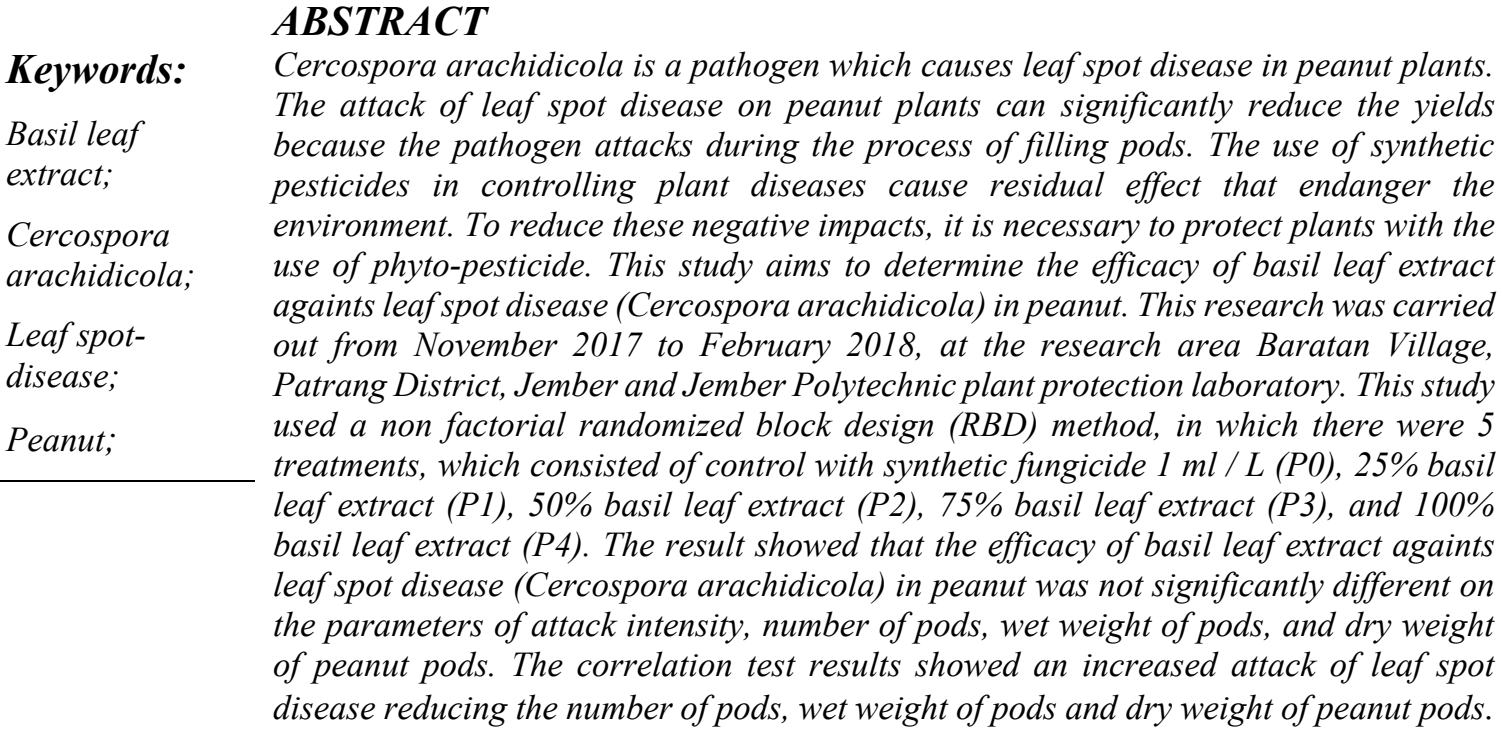




\section{PENDAHULUAN}

Serangan hama dan penyakit tidak terlepas pada pembudidayaan kacang tanah. Salah satu penyakit utama yang menyerang kacang tanah adalah penyakit bercak daun yang ditimbulkan oleh Cercospora arachidicola.

Gejala pada tanaman yang terinfeksi oleh penyakit bercak daun yaitu terdapat bercak kecil berwana coklat pada daun bagian bawah berbentuk bulat sampai dengan tidak teratur. Serangan penyakit bercak daun berdampak pada pengurangan jumlah polong dan berat biji per tanaman sehingga menurunkan produksi tanaman sampai 50\% (Semangun, 1991).

Penggunaan pestisida kimia dalam jangka panjang dapat menyebabkan residu dan memicu efek yang berbahaya pada lingkungan dan masyarakat yang mengkonsumsi. Pestisida nabati merupakan cara pengendalian yang ramah lingkungan, mudah untuk didapat dan mudah terurai di alam untuk hama dan penyakit tanaman (Suhartini, Suryadarma, \& Budiwati, 2017)

Penelitian pengendalian jamur patogen telah banyak dilakukan diantaranya penggunaan ekstrak daun kemangi (Ocimum bacilium). Senyawa yang ada tersebut dapat menghambat pertumbuhan Phakopsora pachyrhizi dengan presentase penyelamatan produksi polong kedelai sebesar 69\% (Safitri et al., 2015)

Tujuan penelitian ini untuk mengetahui efikasi ekstrak daun kemangi terhadap penyakit bercak daun (Cercospora arachidicola) pada tanaman kacang tanah. Dengan penggunaan pestisida nabati diharapkan dapat meminimalisir kerusakan lingkungan, mengurangi ketergantungan penggunaan pestisida sintetik dan hasil produksi dapat terselamatkan.

\section{METODE PENELITIAN}

Penelitian dilaksanakan pada November 2017 sampai Februari 2018 di lahan percobaan Desa Baratan, Kecamatan Patrang, Kabupaten Jember.

Penelitian menggunakan Rancangan Acak Kelompok (RAK) non faktorial dengan 5 perlakuan 5 ulangan yang terdiri dari kontrol dengan fungisida sintetik 1 $\mathrm{ml} /$ liter (P0), ekstrak daun kemangi $25 \%$ (P1), ekstrak daun kemangi 50\% (P2), ekstrak daun kemangi $75 \%$ (P3), dan ekstrak daun kemangi $100 \%$ (P4) .

Pelaksanaan kegiatan penelitian meliputi teknis budidaya dengan pembersihan lahan dari gulma dan akarakar pertanaman sebelumnya, pengolahan lahan penelitian, pembuatan bedengan, penanaman kacang tanah, pemeliharaan tanaman, identifikasi Cercospora arachidicola, pembuatan ekstrak kemangi, pengamatan intensitas Cercospora arachidicola dan pemanenan.

Parameter pengamatan meliputi hasil produksi yang terdiri dari berat polong per rumpun, berat kering per rumpun, dan jumlah polong per rumpun dan pengamatan intensitas serangan Cercospora arachidicola.

Data penelitian efikasi ekstrak daun kemangi (Ocimum basilicum) terhadap penyakit bercak daun (Cercospora arachidicola) pada tanaman kacang tanah diuji dengan uji Analysis of Variance (ANOVA). 


\section{HASIL DAN PEMBAHASAN}
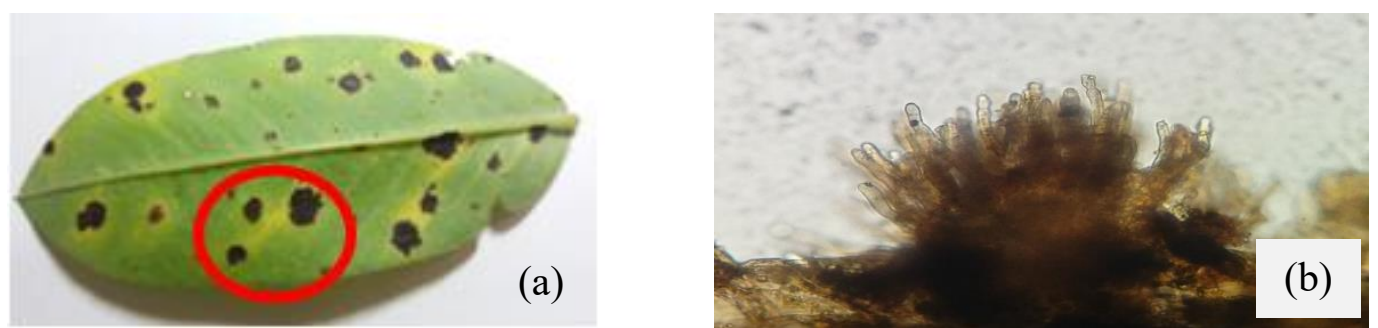

Gambar 1. Penampakan Cercospora arachidicola secara makroskopis (a) dan secara mikroskopis (40x) pada tanaman kacang tanah (b)

Pengamatan di lahan penelitian pada tanaman kacang tanah yang telah terinfeksi oleh Cercospora arachidicola penyebab penyakit bercak daun menunjukkan bahwa secara makroskopis terdapat gejala yang timbul yaitu berupa bercak-bercak dengan bentuk bulat sampai tidak teratur. Gejala bercak daun muncul pada permukaan daun kacang tanah dengan warna coklat, halo kuning sampai coklat kehitam-hitaman, sedangkan secara mikroskopis memiliki konidium yang tumbuh membentuk rumpun, berbentuk tabung panjang dengan lekuk seperti lutut (Sumartini, 2008). Menurut Utomo et al., (2005) terjadinya penyakit bercak daun didukung dengan tersedianya inokulum dalam jumlah yang cukup dan kondisi lingkungan tempat tumbuh.

Pada Tabel 4.1 analisis sidik ragam uji efikasi ekstrak daun kemangi (Ocimum basilicum) terhadap penyakit bercak daun (Cercospora arachidicola) pada tanaman kacang tanah pada 8 MST sampai 12 MST memberikan pengaruh berbeda tidak nyata (non significant). Penggunaan pestisida nabati ekstrak daun kemangi bekerja dengan cara menghambat perkembangan jamur. Kemampuan kandungan senyawa aktif fenol yang terkandung dalam ekstrak daun kemangi yaitu sebagai antifungi (Sumartini, 2008). Selain itu senyawa linalol,estragol, dan eugenol pada ekstrak kemangi berperan juga dalam proses penghambatan jamur (Zahra et al., 2017).

Perlakuan pestisida sintetik dengan bahan aktif heksakonazol dan pestisida ektrak daun kemangi pada beberapa konsentrasi menunjukkan efikasi yang sama terhadap intensitas Cercospora arachidicola. Pengamatan menunjukkan bahwa bercak Cercospora arachidicola terus berkembang pada tanaman dengan penyemprotan pestisida sintetik maupun pestisida ekstrak daun kemangi. Hal ini diduga faktor abiotik seperti unsur iklim yang meliputi suhu, kelembapan, dan curah hujan yang tinggi pada periode penelitian.

Tabel 1. Rerata Presentase Intensitas Serangan Penyakit Bercak Daun (Cercospora arachidicola) Pada Tanaman Kacang Tanah

\begin{tabular}{ccccccccccc}
\hline Perlakuan & \multicolumn{2}{c}{ 8 MST $( \pm$ SD $)$} & \multicolumn{2}{c}{ 9 MST $( \pm$ SD $)$} & 10 MST $( \pm$ SD $)$ & 11 MST $( \pm$ SD $)$ & \multicolumn{2}{c}{12 MST $( \pm$ SD $)$} \\
\hline P0 & $24,12 \pm 3,21$ & a & $31,28 \pm 2,23$ & a & $39,23 \pm 2,93$ & a & $44,89 \pm 2,43$ & a & $51,05 \pm 6,19$ & a \\
P1 & $20,44 \pm 1,41$ & a & $27,86 \pm 1,26$ & a & $35,84 \pm 2,28$ & a & $40,50 \pm 3,36$ & a & $44,56 \pm 2,77$ & a \\
P2 & $21,75 \pm 3,02$ & a & $28,88 \pm 2,10$ & a & $37,84 \pm 2,76$ & a & $43,22 \pm 4,52$ & a & $46,98 \pm 3,93$ & a \\
P3 & $22,29 \pm 2,85$ & a & $29,62 \pm 2,86$ & a & $38,88 \pm 5,49$ & a & $43,85 \pm 3,35$ & a & $48,02 \pm 4,20$ & a \\
P4 & $23,61 \pm 4,17$ & a & $29,63 \pm 5,86$ & a & $38,22 \pm 8,01$ & a & $45,00 \pm 5,86$ & a & $48,40 \pm 5,92$ & a \\
\hline
\end{tabular}

Keterangan: Angka rerata pada tabel dengan huruf sama dalam kolom tabel yang sama menunjukkan pengaruh berbeda tidak nyata 
Proses infeksi diduga terjadi pada daun dalam kondisi basah. Kondisi suhu yang agak tinggi $\left(25^{\circ} \mathrm{C}-30^{\circ} \mathrm{C}\right)$ disertai kondisi kelembapan yang tinggi dapat memacu proses perkembangan dan infeksi penyakit bercak daun pada tanaman kacang tanah (Meliyana, Wardana, \& Syarief, 2019).

Suhardi (2007) menyatakan bahwa hujan merupakan salah satu agen penyebaran konodia patogen, hal ini dikarenakan meningkatnya kelembapan yang disebabkan oleh hujan akan berpengaruh pada daya hidup atau proses infeksi konodia patogen pada tanaman. Hujan juga dapat menurunkan efektivitas fungisida dalam pencucian kandungan bahan aktif pada fungisida yang digunakan. Dalam penelitian Saleh dan Hadi (2011) menyebutkan bahwa sebagian dari fungisida pada tanaman tercuci oleh air hujan diduga disebabkan oleh curah hujan yang tinggi dan mengakibatkan kurang efektifnya penggunaan fungisida pada penelitian.

Tabel 2 Rerata Jumlah Polong Kacang Tanah dan Berat Polong (per sampel)

\begin{tabular}{ccccccccc}
\hline \multirow{2}{*}{ Perlakuan } & \multicolumn{3}{c}{ Jumlah Polong $( \pm$ SD) } & \multicolumn{4}{c}{ Berat Polong $( \pm$ SD $)$} \\
\cline { 2 - 10 } & \multicolumn{2}{c}{ Jumlah Polong } & \multicolumn{2}{c}{ Polong Bernas } & \multicolumn{2}{c}{ Berat Polong Basah } & Berat polong kering \\
\hline P0 & $20,27 \pm 3,34$ & a & $17,47 \pm 3,40$ & a & $26,57 \pm 4,35$ & a & $13,02 \pm 2,20$ & a \\
P1 & $22,50 \pm 1,83$ & a & $19,63 \pm 1,95$ & a & $32,86 \pm 4,44$ & a & $18,13 \pm 2,45$ & a \\
P2 & $20,47 \pm 5,47$ & a & $17,57 \pm 4,36$ & a & $27,01 \pm 8,79$ & a & $14,24 \pm 4,45$ & a \\
P3 & $20,40 \pm 2,34$ & a & $17,33 \pm 1,90$ & a & $27,03 \pm 4,37$ & a & $13,79 \pm 2,06$ & a \\
P4 & $20,40 \pm 4,99$ & a & $16,77 \pm 4,41$ & a & $27,06 \pm 7,22$ & a & $13,51 \pm 3,59$ & a \\
\hline
\end{tabular}

Keterangan: Angka rerata pada tabel dengan huruf sama dalam kolom tabel yang sama menunjukkan pengaruh berbeda tidak nyata

Tabel 2 menunjukkan bahwa aplikasi fungisida sintetik dan fungisida ekstrak daun kemangi berbagai konsentrasi berbeda tidak nyata (non significant) terhadap komponen hasil kacang tanah diantaranya jumlah polong, berat polong basah dan berat polong kering. Berkurangnya hasil dan komponen hasil kacang tanah disebabkan karena tingginya intensitas serangan pernyakit bercak daun pada tanaman. Wahyudin et al., (2015) menyatakan bahwa tanaman yang terserang penyakit pada bagian daun dapat mempengaruhi proses fotosintesis pada tanaman menjadi terbatas sehingga perkembangan polong dan biji terhambat.
Energi dalam bentuk ATP dan NADPH yang berkurang akibat hasil fotosintesis yang tidak sempurna akan mempengaruhi pertumbuhan generatif sehingga berdampak pada produktivitas tanaman (Fitriana et al., 2009).

Terbatasnya hasil fotosintat untuk pembentukan polong menyebabkan hasil polong rendah (Inayati et al., 2016). Hal ini sejalan dengan korelasi negatif pada gambar 2 yang dihasilkan antara intensitas serangan penyakit hasil kacang tanah. Tidak sempurnanya proses fotosintesis yang berlangsung berakibat pada berkurangnya pembentukan karbohidrat dan menghambat proses inisiasi polong (Buge et al., 2017). 


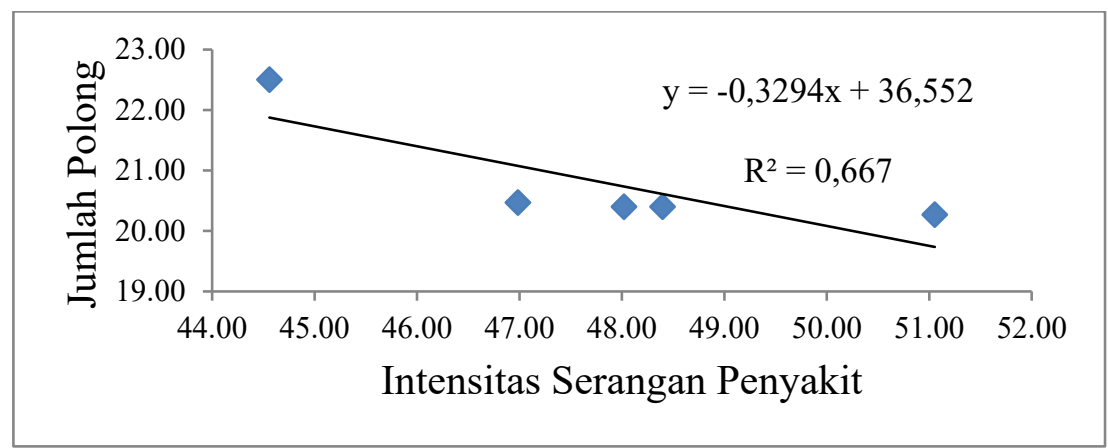

(a)

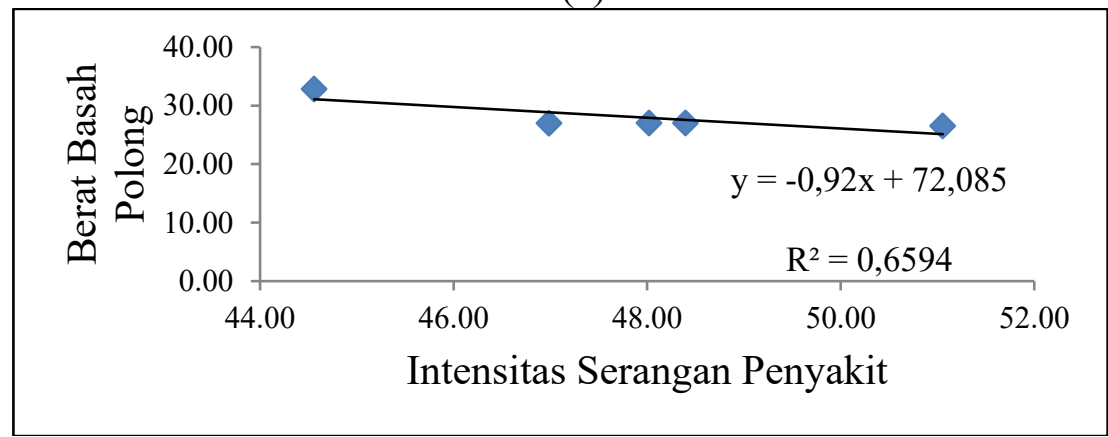

(b)

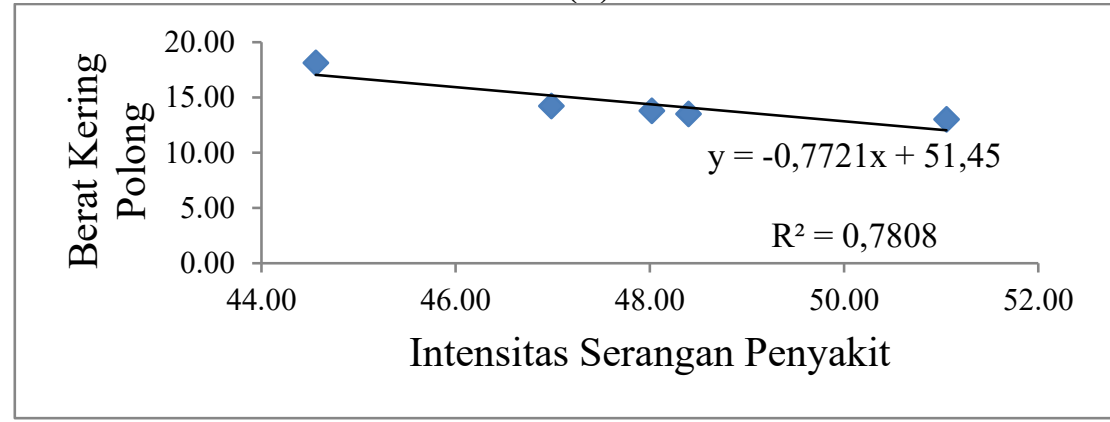

(c)

Gambar 2. Grafik Korelasi antara ISP bercak daun dan (a) Jumlah Polong (b) Berat Basah Polong serta (c) Berat Kering Polong

\section{KESIMPULAN}

Berdasarkan hasil penelitian Efikasi Ekstrak Daun Kemangi (Ocimum Basilicum) Terhadap Penyakit Bercak Daun (Cercospora Arachidicola) Pada Tanaman Kacang Tanah, diperoleh kesimpulan sebagai berikut :

1. Aplikasi perlakuan ekstrak daun kemangi dan pestisida sintetik berpengaruh tidak nyata terhadap intensitas serangan penyakit bercak daun pada tanaman kacang tanah.

2. Aplikasi perlakuan ekstrak daun kemangi dan pestisida sintetik berpengaruh tidak nyata terhadap jumlah polong, berat polong basah dan berat polong kering tanaman kacang tanah.

\section{DAFTAR PUSTAKA}

Buge, V. E., Tarore, A. E., \& Q Lumingkewas, A. M. (2017). Masa Tanam Kacang Tanah (Arachis hypogaea L.) Berdasarkan Neraca Air Di Kecamatan Kakas Barat. Cocos, 1(4), 1-9.

Fitriana, J., Pukan, K. K., \& Herlina, L. EQ (2009). Aktivitas Enzim Nitrat Reduktase Kedelai Kultivar Burangrang akibat Variasi Kadar Air Tanah pada Awal Pengisian Polong. Biosaintivika, 1(1). 
Inayati, A., \& Yusnawan, E. (2016).

Tanggap Genotipe Kacang Tanah Terhadap Penyakit Bercak Daun Cercospora Dan Karat Daun Puccinia. Jurnal Fitopatologi Indonesia, 12(1), 9-18.

Meliyana, R., Wardana, R., \& Syarief, M. E (2019). Efikasi Ekstrak Daun Kemangi (Ocimum basilicum) Terhadap Penyakit Bercak Daun (Cercospora arachidicola) Pada Tanaman Kacang Tanah. Agriprima, Journal of Applied Agricultural Sciences, 3(1), 31-40.

Safitri, N., Sastrahidayat, I. R., \& EQ Muhibuddin, A. (2015). Pemanfaatan Bahan Nabati Ekstrak Daun Kemangi (Ocimum bacilicum L), Daun Sirih (Piper bettle Linn) dan Daun Salam (Syzygium polyanthum), Dalam Pencegahan Serangan Penyakit Karat (Phakospora pachyrhizi Sydow) Pada Tanaman Kedelai (Glycine max L). Jurnal HPT, 3(3), 52-62.

Saleh, N., \& Hadi, M. (2011). EQ Pengendalian Kimiawi Penyakit Bercak Daun Coklat Cercospora henningsii Pada Ubi Kayu. Seminar Hasil Penelitian Tanaman Aneka Kacang Dan Umbi, 610-620.

Semangun, H. (1991). Penyakit-Penyakit 县 Tanaman Pangan Di Indonesia (Edisi Kedua).

Suhardi. (2007). Efektivitas Fungisida Untuk Pengendalian Penyakit Berdasarkan Curah Hujan Pada Mawar. Jurnal Hortikultura, 17(4), 355-364.

Suhartini, S., Suryadarma, P., \& Budiwati, B. (2017). Pemanfaatan Pestisida Nabati Pada Pengendalian Hama
Plutella Xylostella Tanaman Sawi (Brassica Juncea L.) Menuju Pertanian Ramah Lingkungan. Jurnal Sains Dasar, 6(1), 36.

Sumartini. (2008). Bioekologi dan EQ Pengendalian Penyakit Bercak Daun Pada Kacang Tanah. Buletin Palawija, (16), 18-26.

Utomo, S. D., Setiowati, E., \& Akin, H. M. E (2005). Ketahanan Terhadap Penyakit Bercak Daun Lambat ( Cercosporidium personatum ) Dan Karakter Agronomi Kacang Tanah Famili F5 Keturunan Persilangan Kelinci x Southern Runner. Jurnal HPT Tropika, 5(2), 104-112.

Wahyudin, A., Nurmala, T., \& Rahmawati, E. D. (2015). Pengaruh Dosis Pupuk Fosfor dan Pupuk Organik Cair Terhadap Pertumbuhan dan Hasil Kacang Hijau ( Vigna radiata L .) Pada Ultisol Jatinangor. Jurnal Kultivasi, 14(2), 16-22.

Zahra, S., \& Iskandar, Y. (2017). Q Kandungan Senyawa Kimia Dan Bioaktivitas Ocimum basilicum L. Farmaka, 15(3), 143-152. 